POLITICAL PARTIES AND NATIONAL

INTEGRATION IN TROPICAL AFRICA

Published under the auspices of the African Studies Center University of Califormia, Los Angeles 



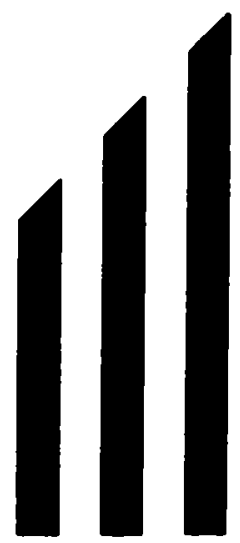

\title{
POLITICAL PARTIES AND
}

\section{NATIONAL INTEGRATION IN}

\section{TROPICAL AFRICA}

\author{
EDITED BY JAMES S. COLEMAN \\ A ND CARL G. ROSBERG, JR.
}

University of California Press

BERKELEY ANDLOS ANGELES

1966 


\section{University of California Press}

Berkeley and Los Angeles Cambridge University Press London, England

(C) 1964 by The Regents of the University of California

Second Printing, 1966 Library of Congress Catalog Card No. 64-19636

Designed by Ward Ritchie Printed in the United States of America 